\title{
PARAMETER ORGANOLEPTIK NORI DAUN KELOR (Moringa oleifera) DENGAN VARIASI KONSENTRASI KAPPA KARAGENAN DAN SUHU PENGERINGAN
}

\author{
Organoleptic Parameters of Moringa Leaf Nori (Moringa oleifera) with Variation \\ of Kappa Carrageenan Consentration and Drying Temperature
}

\author{
Intannisa Nazwa, Dwi Lestari Rahayu \\ Program Studi Pendidikan Teknologi Agroindustri, Fakultas Pendidikan Teknologi dan Kejuruan \\ Universitas Pendidikan Indonesia, Bandung, Indonesia \\ E-mail: nazwa02@student.upi.edu
}

\begin{abstract}
ABSTRAK
Daun kelor dapat menjadi bahan substitusi nori siap makan. Pada proses pembuatannya, penggunaan konsentrasi karagenan dan suhu pengeringan yang tepat merupakan faktor yang penting. Oleh karena itu, penelitian ini dilakukan dengan tujuan untuk mengetahui hasil penilaian karakteristik organoleptik (warna, aroma, rasa dan kelenturan) nori daun kelor siap makan dengan variasi konsentrasi kappa karagenan dan suhu pengeringan. Penelitian ini menggunakan rancangan dua faktor yaitu variasi konsentrasi kappa karagenan $(1.5 \%, 2 \%$ dan $2.5 \%)$ dan suhu pengeringan $\left(45^{\circ} \mathrm{C}, 50^{\circ} \mathrm{C}\right.$ dan $\left.55^{\circ} \mathrm{C}\right)$. Penilaian karakteristik organoleptik dilakukan melalui uji hedonik dan mutu hedonik pada parameter warna, aroma, rasa dan kelenturan oleh 15 panelis semi terlatih. Pada parameter rasa, nori daun kelor dengan karagenan $1.5 \%$ dan suhu pengeringan $50^{\circ} \mathrm{C}$ dan $55^{\circ} \mathrm{C}$ memiliki hasil uji hedonik yang lebih rendah yaitu berada pada kategori antara tidak suka dan biasa sedangkan perlakuan lainnya berada pada kategori antara biasa dan suka. Pada parameter kelenturan, nori dengan karagenan $2 \%$ dan $2.5 \%$ pada suhu pengeringan $55^{\circ} \mathrm{C}$ berada pada kategori antara tidak suka dan biasa sedangkan pada perlakuan suhu lainnya berada pada kategori antara biasa dan suka. Hasil uji mutu hedonik parameter warna menunjukkan bahwa nori daun kelor yang dikeringkan pada suhu $45^{\circ} \mathrm{C}$ dan $55^{\circ} \mathrm{C}$ dinilai memiliki warna yang lebih hijau dibandingkan dengan pengeringan suhu $50^{\circ} \mathrm{C}$. Pada parameter aroma, nori daun kelor yang dikeringkan pada suhu $50^{\circ} \mathrm{C}$ lebih tidak beraroma daun dibandingkan dengan penggunaan suhu lain. Pada parameter kelenturan, nori menjadi semakin tidak lentur ketika suhu pengeringan dan konsentrasi kappa karagenan yang digunakan semakin tinggi.
\end{abstract}

Kata kunci: daun kelor, nori, suhu pengeringan, karagenan

\begin{abstract}
Moringa leaf can be used as substitution of red algae in making ready-to-eat nori. The precisely of carrageenan concentration and drying temperature are two important factors in moringa leave nori processing. Therefore, the purpose of this research is to discover the valuation of organoleptic characteristics (color, aroma, taste and elasticity) moringa leaf nori with cappa carrageenan concentration and drying temperature variations. This research used two-factor design, those are carrageenan concentration $(1.5 \%, 2 \%$, and $2.5 \%)$ and drying temperature $\left(45^{\circ} \mathrm{C}, 50^{\circ} \mathrm{C}\right.$ and $\left.55^{\circ} \mathrm{C}\right)$. Organoleptic characteristic valuation is obtained through hedonic and hedonic quality test in parameter of color, aroma, taste and elasticity by 15 semi trained panelists. In taste parameter, moringa leaf nori with $1.5 \%$ of kappa carrageenan addition and drying temperature at $50^{\circ} \mathrm{C}$ and $55^{\circ} \mathrm{C}$ have less favorability those are between dislike and neutral than moringa leaf nori with other cappa carrageenan concentration those range between neutral and like. In elasticity parameter, moringa leaf nori those dried at $55^{\circ} \mathrm{C}$ with $2 \%$ and $2.5 \%$ cappa carrageenan addition have less favorability than moringa leaf nori those dried at the other temperature. From the result of hedonic quality, moringa leaf nori those are dried at $45^{\circ} \mathrm{C}$ and $50^{\circ} \mathrm{C}$ tend to have more green color than the one's dried at $55^{\circ} \mathrm{C}$. In aroma parameter, it is known that drying temperature of $50^{\circ} \mathrm{C}$ produced preferred aroma of ready-toeat moringa leaf nori. In elasticity parameter, the increaseing of kappa carrageenan concentrarion and drying temperature tends to make moringa leaf nori become less elastic.
\end{abstract}

Keywords: moringa leaf, nori, drying temperature, carrageenan 


\section{PENDAHULUAN}

Dewasa ini, pengaruh budaya negara-negara Asia seperti Korea, Jepang, dan Cina semakin terasa di Indonesia. Pengaruh yang diberikan negara-negara Asia tersebut bukan hanya dalam ranah hiburan dan teknologi, namun juga merambat pada gaya hidup seperti jenis makanan untuk konsumsi. Di kota-kota besar di Indonesia, jumlah usaha rumah makan berskala menengah dan besar yang menyajikan jenis masakan asing selain didominasi masakan Western adalah jenis masakan Cina, Jepang dan Korea. Selama tahun 2014 sampai 2015 terdapat pertumbuhan usaha rumah makan berskala menengah dan besar yang menyajikan masakan utama Cina, Jepang dan Korea. Persentase peningkatan jenis masakan utama Cina naik hingga 320,53\%, Jepang 143,18\%, dan Korea 215,12\% (Badan Pusat Statistik, 2015).

Nori atau rumput laut kering adalah salah satu bahan makanan yang umumnya tersedia di restoran Jepang, Korea, dan China. Saat ini masyarakat Indonesia menujukkan ketertarikan terhadap nori yang dapat dilihat dari banyaknya produk nori dalam kemasan yang beredar di pasaran (Syarifah, 2016). Nori dapat dikonsumsi sebagai bahan penyalut (coating) maupun camilan atau snack. Snack atau camilan merupakan jenis makanan sekunder yang sangat diminati oleh masyarakat. Hal tersebut dikarenakan beberapa faktor seperti berbagai varian rasa, tekstur yang renyah, harga yang variatif, kemasan yang menarik, masa simpan yang panjang, dan bentuk yang beraneka ragam. Kenaikan konsumsi snack dari tahun 2011-2015 adalah 2,21\%. Setiap minggunya, rata-rata orang Indonesia mengonsumsi makanan ringan atau snack sebanyak 100 gram (Pusdatin, 2015).

Nori yang terbuat dari alga merah, Porphyra yezoensis adalah yang paling sering dikonsumsi di Asia dan Asia Selatan (Kim dkk., 2014). Rumput laut jenis Porphyra yezoensis tersebut masih sangat sulit diperoleh di Indonesia. Di Indonesia, rumput laut tersebut hanya dapat dihasilkan di beberapa daerah saja seperti Provinsi Papua, NTB (Burhani, 2007) dan Ambon (Hatta, 1990), sehingga Indonesia masih harus mengimpor untuk mencukupi kebutuhan nori. Penggunaan sumber bahan baku alternatif diperlukan untuk memproduksi jenis camilan serupa nori dan memaksimalkan potensi sumber pangan lokal tanpa ketergantungan pada bahan pangan impor (Agusta dkk., 2017).

Salah satu sumber pangan alternatif yang dapat digunakan sebagai substitusi Porphyra yezoensis adalah daun kelor. Di Indonesia, pemanfaatan daun kelor belum maksimal dan masih terbatas pada pelengkap makanan sehari-hari maupun sekedar menjadi tanaman hias (Dewi dkk., 2016). Daun kelor kaya akan nutrisi seperti mineral, serat dan protein yang memainkan peran penting dalam konsumsi gizi manusia. Daun kelor mengandung asam amino esensial yang sama tingginya dengan jumlah protein, kalsium, dan vitamin A yang dimilikinya (Olson dkk., 2016). Banyak penelitian yang menyebutkan bahwa daun kelor memiliki protein yang tinggi dibanding dengan daun lain yang biasa dikonsumsi sebagai makanan (Dada, 2016), serta memiliki kandungan asam amino yang tidak jauh berbeda dengan asam amino pada telur ayam dan daging sapi (Olaofe dkk., 2013 dan Muchtadi \& Sugiono, 1992).

Berbeda dengan rumput laut, daun kelor tidak memiliki karagenan sebagai bahan pengikat. Oleh karena itu, dalam pembuatan nori daun kelor diperlukan penambahan karagenan sebagai bahan pengikat. Penelitian Rianse (2017) menunjukkan bahwa kappa karagenan dapat digunakan dalam pembuatan nori daun kelor, namun nori daun kelor yang dihasilkan memerlukan proses pemanasan yang panjang berkisar 11-12 jam pada suhu $60^{\circ} \mathrm{C}$ sehingga menyebabkan kemampuan karagenan menjadi tidak optimal. 
Lamanya waktu pengeringan juga membuat proses pembuatan nori menjadi kurang efisien dan kurang ekonomis. Lamanya waktu pengeringan dipengaruhi oleh ketebalan bubur/adonan saat pencetakan dan rendahnya konsentrasi karagenan yang ditambahkan.

Pada penelitian tahap awal, peneliti mencoba mencari ketebalan bubur/adonan yang baik saat pencetakan, menetapkan suhu yang digunakan, menetapkan waktu pengeringan yang diperlukan dan besarnya konsentrasi karagenan yang dinilai cukup tepat untuk pembuatan nori daun kelor. Dari hasil penelitian tahap awal, ditetapkan faktor perlakuan adalah bubur/adonan dengan ketebalan $0.5 \mathrm{~cm}$ pada suhu $45^{\circ}, 50^{\circ}$, dan $55^{\circ} \mathrm{C}$ selama 7.5 jam pada penambahan konsentrasi karagenan sebanyak $1.5 \%, 2 \%$ dan $2.5 \%$. Tujuan dari penelitian ini adalah untuk mengetahui hasil penilaian parameter organoleptik (warna, aroma, rasa, dan kelenturan) nori daun kelor siap makan dengan variasi konsentrasi kappa karagenan dan suhu pengeringan.

\section{METODE}

\section{Alat}

Peralatan yang digunakan dalam penelitian ini adalah oven etuve universelle ventilée XU058, blender, loyang stainless steel ukuran 11.5 x $12 \mathrm{~cm}$, timbangan, sendok, baskom, neraca analitik, dan gelas ukur.

\section{Bahan}

Bahan yang digunakan dalam penelitian ini adalah daun kelor yang didapat dari daerah Riung Bandung Kota Bandung, kappa karagenan merk IndoGum, air steril, dan margarin cair.

\section{Prosedur Pembuatan Nori Daun Kelor Siap Makan}

Prosedur pembuatan nori daun kelor siap makan pada penelitian ini mengacu pada penelitian Rianse (2017) dan Agusta (2017). Daun kelor segar disortasi kemudian dicuci menggunakan air mengalir. Daun kelor yang telah bersih ditimbang sebanyak 20 gram. Selanjutnya karagenan 1,5\%,2\%,2,5\% (b/v) dilarutkan dalam $100 \mathrm{ml}$ air. Larutan karagenan dicampurkan dengan daun kelor dan ditambahkan $100 \mathrm{ml}$ air kemudian dihancurkan menggunakan blender selama 1 menit. Setelah homogen, bubur kelor yang telah tercampur dengan karagenan kemudian dicetak dengan ketebalan $0,5 \mathrm{~cm}$ pada loyang yang sudah diolesi margarin cair. Proses selanjutnya adalah pengeringan dengan suhu $45^{\circ} \mathrm{C}, 50^{\circ} \mathrm{C}, 55^{\circ} \mathrm{C}$ selama 7.5 jam. Nori daun kelor yang telah kering selanjutnya dilakukan uji organoleptik hedonik dan mutu hedonik.

\section{Rancangan Percobaan}

Pada penelitian ini digunakan rancangan dua faktor yaitu suhu pengeringan dan konsentrasi karagenan. Percobaan dilakukan sebanyak 2 kali ulangan. Rancangan penelitian dapat dilihat pada Tabel 1. 
Tabel 1. Rancangan Penelitian

\begin{tabular}{ccccc}
\hline \multirow{2}{*}{ Suhu Pengeringan } & \multirow{2}{*}{ Ulangan $(\mathbf{r})$} & \multicolumn{3}{c}{ Konsentrasi Karagenan } \\
\cline { 3 - 5 } & & B1 (1.5\%) & B2 (2\%) & B3 (2.5\%) \\
\hline \multirow{2}{*}{$A 1\left(45^{\circ} \mathrm{C}\right)$} & 1 & $(\mathrm{~A} 1 \mathrm{~B} 1)_{1}$ & $(\mathrm{~A} 1 \mathrm{~B} 2)_{1}$ & $(\mathrm{~A} 1 \mathrm{~B} 3)_{1}$ \\
& 2 & $(\mathrm{~A} 1 \mathrm{~B} 1)_{2}$ & $(\mathrm{~A} 1 \mathrm{~B} 2)_{2}$ & $(\mathrm{~A} 1 \mathrm{~B} 3)_{2}$ \\
\hline \multirow{2}{*}{$\mathrm{A} 2\left(50^{\circ} \mathrm{C}\right)$} & 1 & $(\mathrm{~A} 2 \mathrm{~B} 1)_{1}$ & $(\mathrm{~A} 2 \mathrm{~B} 2)_{1}$ & $(\mathrm{~A} 2 \mathrm{~B} 3)_{1}$ \\
& 2 & $(\mathrm{~A} 2 \mathrm{~B} 1)_{2}$ & $(\mathrm{~A} 3 \mathrm{~B} 2)_{2}$ & $(\mathrm{~A} 3 \mathrm{~B})_{2}$ \\
\hline \multirow{2}{*}{$\mathrm{A} 3\left(55^{\circ} \mathrm{C}\right)$} & 1 & $(\mathrm{~A} 3 \mathrm{~B} 1)_{1}$ & $(\mathrm{~A} 3 \mathrm{~B} 2)_{1}$ & $(\mathrm{~A} 3 \mathrm{~B} 3)_{1}$ \\
& 2 & $(\mathrm{~A} 3 \mathrm{~B} 1)_{2}$ & $(\mathrm{~A} 3 \mathrm{~B} 2)_{2}$ & $(\mathrm{A3B} 3)_{2}$ \\
\hline
\end{tabular}

Pada pengujian organoleptik hedonik dan mutu hedonik, panelis diminta untuk menguji sampel yang diberikan berdasarkan tingkat kesukaan dan parameter organoleptik yang diamati. Parameter yang diuji pada penelitian ini adalah parameter warna, aroma, rasa, dan kelenturan. Setelah mengamati dan menguji parameter tersebut, panelis diminta untuk menginterpretasikan kesan yang ditangkap dalam nilai skala 1 hingga 5 . Nilai dan parameter pengukuran uji hedonik dan mutu hedonik dapat dilihat pada Tabel 2.

Tabel 2. Nilai dan Parameter Hasil Pengukuran Uji Hedonik dan Mutu Hedonik

\begin{tabular}{|c|c|c|c|c|c|}
\hline \multirow{2}{*}{ Nilai } & \multirow{2}{*}{ Uji Hedonik } & \multicolumn{4}{|c|}{ Uji Mutu Hedonik } \\
\hline & & Warna & Aroma & Rasa & Kelenturan \\
\hline 1 & $\begin{array}{l}\text { Sangat } \\
\text { tidak suka }\end{array}$ & $\begin{array}{l}\text { Sangat tidak } \\
\text { hijau }\end{array}$ & $\begin{array}{l}\text { Sangat tidak } \\
\text { beraroma daun }\end{array}$ & $\begin{array}{l}\text { Sangat tidak } \\
\text { pahit }\end{array}$ & $\begin{array}{l}\text { Sangat tidak } \\
\text { lentur }\end{array}$ \\
\hline 2 & Tidak suka & Tidak hijau & $\begin{array}{l}\text { Tidak beraroma } \\
\text { daun }\end{array}$ & Tidak pahit & Tidak lentur \\
\hline 3 & Biasa & Agak hijau & $\begin{array}{l}\text { Agak beraroma } \\
\text { daun }\end{array}$ & Agak pahit & Agak lentur \\
\hline 4 & Suka & Hijau & Beraroma daun & Pahit & Lentur \\
\hline 5 & $\begin{array}{l}\text { Sangat } \\
\text { suka }\end{array}$ & Sangat hijau & $\begin{array}{l}\text { Sangat beraroma } \\
\text { daun }\end{array}$ & Sangat pahit & Sangat lentur \\
\hline
\end{tabular}

\section{HASIL DAN PEMBAHASAN}

\section{Uji Hedonik dan Mutu Hedonik Warna Nori Daun Kelor}

Warna merupakan atribut sensori pertama yang dapat diidentifikasi langsung oleh panelis. Warna dapat menentukan mutu dari bahan, warna yang tidak menyimpang dari warna yang seharusnya dimiliki suatu bahan akan memberikan kesan penilaian tersendiri pada panelis (Negara dkk. 2016). Hasil uji hedonik dan mutu hedonik nori daun kelor dapat dilihat pada Tabel 3 dan 4.

Pada Tabel 3 diketahui bahwa semua sampel memiliki tingkat kesukaan yang sama yakni diantara kategori 'biasa' dan 'suka'. Hasil ini sejalan dengan penelitian Rianse (2017) yang mengatakan bahwa konsentrasi karagenan tidak memengaruhi tingkat kesukaan warna produk. Meski masuk dalam kategori yang sama dalam tingkat kesukaan, namun pada hasil uji mutu hedonik terdapat beberapa sampel perlakuan yang memiliki warna yang berbeda dari sampel perlakuan lain. 
Bila melihat Tabel 4, terdapat pola nilai yang unik pada sampel perlakuan A1B1, A2B1, dan A3B1. Meski jumlah karagenan yang ditambahkan pada ketiganya sama, namun dikarenakan suhu pengeringan yang berbeda maka hasil yang didapatkan menjadi berbeda. Di mata panelis, A1B1 dan A3B1 memiliki warna yang cenderung lebih hijau dibandingkan dengan A2B1.

Tabel 3. Hasil Uji Hedonik Warna Nori Daun Kelor

\begin{tabular}{cccc}
\hline \multirow{2}{*}{ Suhu pengeringan } & \multicolumn{3}{c}{ Konsentrasi Karagenan } \\
\cline { 2 - 4 } & $\mathrm{B} 1(1.5 \%)$ & $\mathrm{B} 2(2 \%)$ & $\mathrm{B} 3(2.5 \%)$ \\
\hline $\mathrm{A} 1\left(45^{\circ} \mathrm{C}\right)$ & 3.37 & 3.73 & 3.40 \\
$\mathrm{~A} 2(500 \mathrm{C})$ & 3.17 & 3.17 & 3.47 \\
$\mathrm{~A} 3\left(55^{\circ} \mathrm{C}\right)$ & 3.17 & 3.83 & 3.47 \\
\hline
\end{tabular}

Keterangan: antara biasa dan suka

Tabel 4. Hasil Uji Mutu Hedonik Warna Nori Daun Kelor

\begin{tabular}{cccc}
\hline \multirow{2}{*}{ Suhu Pengerigan } & \multicolumn{3}{c}{ Konsentrasi Karagenan } \\
\cline { 2 - 4 } & B1 $(1.5 \%)$ & B2 $(2 \%)$ & B3 $(2.5 \%)$ \\
\hline A1 $\left(45^{\circ} \mathrm{C}\right)$ & 4.13 & 4.17 & 3.80 \\
A2 $\left(50^{\circ} \mathrm{C}\right)$ & 3.77 & 3.53 & 3.97 \\
A3 $\left(55^{\circ} \mathrm{C}\right)$ & 4.27 & 3.80 & 4.07 \\
\hline
\end{tabular}

Keterangan: antara agak hijau dan hijau antara hijau dan sangat hijau

Perubahan warna nori daun kelor diduga terjadi karena degradasi klorofil yang diikuti dengan munculnya pigmen likopen (Patriyanti, 2016). Meningkatnya suhu yang digunakan menjadikan warna daun kelor menjadi hijau tua dan menurunnya nilai kecerahan daun (Ali dkk., 2014). Warna hijau natural dari daun merupakan hasil dari pencampuran senyawa dalam klorofil yang secara langsung berhubungan denga magnesium. Selama proses pengeringan, molekul-molekul magnesium berubah menjadi pirofeofitin dan feofitin (Buchaillot dkk., 2009 dalam Ali dkk., 2014). Suhu yang tinggi menyebabkan denaturasi protein dan membuat $\mathrm{pH}$ menjadi asam. Pada proses pengeringan, terjadi denaturasi protein pelindung kloroplas sehingga ion $\mathrm{Mg}$ mudah terlepas dan digantikan oleh ion hidrogen dan membentuk feofitin. Proses pemanasan juga menjadikan $\mathrm{pH}$ menjadi asam sehingga membuat klorofil menjadi tidak stabil yang memicu terjadinya feofitinisasi (Arfandi, 2013). Bila mengacu pada pendapat di atas, maka perlakuan A1B1 terlihat lebih hijau dibanding A2B1 karena A1B1 memiliki warna hijau yang cerah sedangkan A2B1 kecerahannya sudah menurun. Pada A3B1 walaupun kecerahannya menurun, warna hijaunya lebih tua dan lebih terlihat hijau menurut panelis dibandingkan dengan perlakuan A2B1 (Gambar 1). 


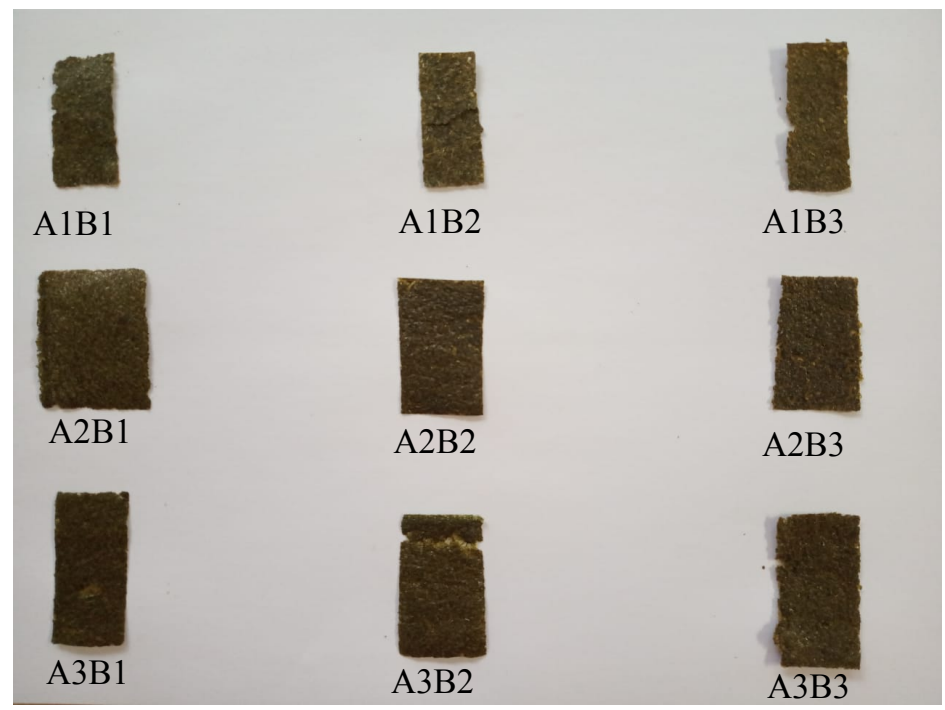

Gambar 1. Nori Daun Kelor Siap Makan

\section{Uji Hedonik dan Mutu Hedonik Aroma Nori Daun Kelor}

Aroma merupakan salah satu atribut sensori yang bersamaan dengan rasa menciptakan cita rasa suatu pangan. Aroma dapat memberikan penilaian minat konsumen terhadap suatu produk dengan cepat, sehingga uji terhadap atribut ini dianggap penting (Soekarto, 1995). Pada Tabel 5 mengenai hasil uji hedonik nori daun kelor siap makan pada parameter aroma menunjukkan bahwa seluruh sampel masuk pada kategori penilaian yang sama yakni antara 'biasa' dan 'suka'. Hasil ini sejalan dengan penelitian Marwani dan Yuwono (2018) dimana penambahan karagenan tidak berpengaruh terhadap tingkat kesukaan aroma mix fruit leather.

Tabel 5. Hasil Uji Hedonik Aroma Nori Daun Kelor

\begin{tabular}{cccc}
\hline \multirow{2}{*}{ Suhu Pengeringan } & \multicolumn{3}{c}{ Konsentrasi Karagenan } \\
\cline { 2 - 4 } & $\mathrm{B} 1(1.5 \%)$ & $\mathrm{B} 2(2 \%)$ & $\mathrm{B} 3(2.5 \%)$ \\
\hline $\mathrm{A} 1\left(45^{\circ} \mathrm{C}\right)$ & 3.23 & 3.40 & 3.43 \\
$\mathrm{~A} 2\left(50^{\circ} \mathrm{C}\right)$ & 3.40 & 3.63 & 3.57 \\
$\mathrm{~A} 3\left(55^{\circ} \mathrm{C}\right)$ & 3.03 & 3.23 & 3.17 \\
\hline
\end{tabular}

Keterangan: antara biasa dan suka

Data pada Tabel 5 juga menunjukkan bahwa nori yang dikeringkan pada suhu $50^{\circ} \mathrm{C}$ cenderung lebih disukai panelis dimana pada suhu ini aroma nori yang dihasilkan lebih tidak berbau daun dibandingkan dengan nori yang dikeringkan pada suhu lain. Nori dengan penambahan karagenan $2 \%$ memiliki aroma yang cenderung lebih disukai dibandingkan dengan konsentrasi lain. Suhu pengeringan $50^{\circ} \mathrm{C}$ cenderung menunjukkan tingkat kesukaan yang lebih tinggi sejalan dengan aroma daun yang lebih rendah.

Pada Tabel 6, diketahui bahwa hampir seluruh perlakuan masuk pada kategori 'agak beraroma daun' dan 'beraroma daun' terlepas dari bau langu yang dimiliki daun kelor. Hal ini dikarenakan aroma langu dari daun kelor akan menguap ketika dipanaskan karena sifat volatil yang mudah menguap. 
Berbeda dengan perlakuan lain, perlakuan A3B1 masuk pada kategori 'beraroma daun'. Hal ini diduga karena perpaduan antara suhu yang panas dan penambahan karagenan yang sedikit. Suhu yang tinggi menyebabkan nori mengeluarkan aroma gosong daun, disaat yang bersamaan, efek gelasi dan flavour khas karagenan tidak mampu menutupi aroma tersebut dikarenakan penambahan karagenan yang terlalu sedikit (Stevani dkk., 2018).

Tabel 6. Hasil Uji Mutu Hedonik Aroma Nori Daun Kelor

\begin{tabular}{cccc}
\hline \multirow{2}{*}{ Suhu Pengeringan } & \multicolumn{3}{c}{ Konsentrasi Karagenan } \\
\cline { 2 - 4 } & $\mathrm{B} 1(1.5 \%)$ & $\mathrm{B} 2(2 \%)$ & $\mathrm{B} 3(2.5 \%)$ \\
\hline $\mathrm{A} 1\left(45^{\circ} \mathrm{C}\right)$ & 3.70 & 3.73 & 3.47 \\
$\mathrm{~A} 2\left(50^{\circ} \mathrm{C}\right)$ & 3.20 & 3.27 & 3.30 \\
$\mathrm{~A} 3\left(55^{\circ} \mathrm{C}\right)$ & 4.00 & 3.57 & 3.50 \\
\hline
\end{tabular}

Keterangan: antara agak beraroma daun dan beraroma daun antara beraroma daun dan sangat beraroma daun

\section{Uji Hedonik dan Mutu Hedonik Rasa Nori Daun Kelor}

Rasa merupakan salah satu faktor yang memengaruhi tingkat penerimaan seseorang pada produk pangan. Meski demikian, masing-masing individu memiliki penilaian berbeda terhadap rasa, sehingga sulit untuk menyimpulkan secara objektif (Roiyana dkk., 2011). Hasil uji hedonik pada parameter rasa yang disajikan pada Tabel 7 menunjukkan bahwa hampir seluruh sampel memiliki kategori rasa yang sama yakni diantara kategori 'biasa' dan 'suka'. Hanya sampel A1B1 dan A3B1 yang masuk pada kategori antara 'tidak suka' dan 'biasa'. Kedua sampel ini sama-sama memiliki konsentrasi karagenan $1.5 \%$.

Bila melihat data pada Tabel 7, hasil uji hedonik menunjukkan pada setiap perlakuan suhu pengeringan, nori daun kelor dengan penambahan konsentrasi karagenan $1.5 \%$ menghasilkan rasa yang lebih tidak disukai dibandingkan dengan penambahan konsentrasi lain. Lebih lanjut, pada diagram tersebut terlihat bahwa meningkatnya konsentrasi karagenan menunjukkan kecenderungan panelis terhadap parameter rasa nori daun kelor siap makan menjadi meningkat.

Tabel 7. Hasil Uji Hedonik Rasa Nori Daun Kelor

\begin{tabular}{cccc}
\hline \multirow{2}{*}{ Suhu Pengeringan } & \multicolumn{3}{c}{ Konsentrasi Karagenan } \\
\cline { 2 - 4 } & $\mathrm{B} 1(1.5 \%)$ & $\mathrm{B} 2(2 \%)$ & $\mathrm{B} 3(2.5 \%)$ \\
\hline $\mathrm{A} 1\left(45^{\circ} \mathrm{C}\right)$ & 2.97 & 3.73 & 3.53 \\
$\mathrm{~A} 2\left(50^{\circ} \mathrm{C}\right)$ & 3.10 & 3.17 & 3.53 \\
$\mathrm{~A} 3\left(55^{\circ} \mathrm{C}\right)$ & 2.70 & 3.47 & 3.53 \\
\hline
\end{tabular}

Keterangan: antara tidak suka dan biasa

antara biasa dan suka

Berbeda dengan hasil dari faktor konsentrasi karagenan yang menunjukkan pola konsisten, faktor suhu pengeringan tidak menunjukkan pola yang konsisten pada hasil uji hedoniknya. Hasil ini menunjukkan bahwa faktor konsentrasi karagenan berkonstribusi lebih besar dalam membentuk rasa nori daun kelor dibandingkan dengan faktor suhu pengeringan. Kontribusi karagenan pada parameter rasa baru akan terlihat apabila tidak terdapat penambahan perasa seperti garam dan gula. 
Pada penelitian Rianse (2017) terdapat penambahan garam dan gula sehingga penambahan konsentrasi karagenan tidak memberi efek pada parameter rasa. Berbeda dengan penelitian Stevani dkk. (2018) dimana peneliti tidak memberikan zat perasa sehingga variasi penambahan karagenan memberikan konstribusi dalam pembentukan rasa nori.

Pada uji mutu hedonik, nilai yang kecil menunjukkan semakin sedikit rasa pahit yang terdapat pada nori daun kelor siap makan. Hasil uji mutu hedonik parameter rasa yang terdapat pada Tabel 8 menunjukkan bahwa hampir seluruh sampel memiliki rasa dengan kategori di antara 'tidak pahit' dan 'agak pahit'. Kedua perlakuan yang memiliki rasa antara 'agak pahit' dan 'pahit' adalah perlakuan yang sama dengan perlakuan yang memiliki tingkat kesukaan antara 'tidak suka' dan 'biasa'. Dari kesinergisan hasil antara hedonik dan mutu hedonik ini, maka dapat ditarik kesimpulan bahwa panelis memiliki kecenderungan untuk lebih menyukai nori daun kelor siap makan dengan rasa yang tidak pahit.

Tabel 8. Hasil Uji Mutu Hedonik Rasa Nori Daun Kelor

\begin{tabular}{cccc}
\hline \multirow{2}{*}{ Suhu Pengeringan } & \multicolumn{3}{c}{ Konsentrasi Karagenan } \\
\cline { 2 - 4 } & $\mathrm{B} 1(1.5 \%)$ & $\mathrm{B} 2(2 \%)$ & $\mathrm{B} 3(2.5 \%)$ \\
\hline $\mathrm{A} 1\left(45^{\circ} \mathrm{C}\right)$ & 3.10 & 2.40 & 2.67 \\
$\mathrm{~A} 2\left(50^{\circ} \mathrm{C}\right)$ & 2.93 & 2.73 & 2.63 \\
$\mathrm{~A} 3\left(55^{\circ} \mathrm{C}\right)$ & 3.43 & 2.63 & 2.63 \\
\hline
\end{tabular}

Keterangan: antara tidak pahit dan agak pahit antara agak pahit dan pahit

Lebih lanjut, pada diagram hasil uji mutu hedonik terlihat suatu pola dimana semakin banyak karagenan yang ditambahkan, menunjukkan rasa pahit dari nori daun kelor siap makan cenderung berkurang. Pada penelitian Stevani dkk. (2018) mengenai nori daun kangkung, diketahui bahwa penambahan karagenan berpengaruh nyata dalam pembentukkan rasa nori daun kangkung. Hal ini disebabkan oleh flavour karagenan yang khas, sehingga menyamarkan flavour asli dari bahan yang digunakan. Menguatkan pendapat tersebut, Harijono dkk. (2001) berpendapat bahwa efek gelasi yang tinggi yang dimiliki karagenan mampu menutupi rasa dan aroma yang dimiliki bahan. Jika mengacu pada kedua pendapat tersebut, maka hal yang sama terjadi pada rasa nori daun kelor siap makan dimana rasa pahit dari nori daun kelor tersamarkan oleh flavour khas dan efek gelasi yang tinggi yang dimiliki karagenan.

\section{Uji Hedonik dan Mutu Hedonik Kelenturan Nori Daun Kelor}

Kelenturan merupakan salah satu bagian dari tekstur. Kelenturan yang diinginkan dari nori daun kelor siap makan pada penelitian ini adalah nori daun kelor yang tidak terlalu lentur namun tetap bisa digulung seperti snack nori yang berada di pasaran. Meski demikian, tingkat kesukaan tiap individu dapat berbeda-beda tergantung pada kecenderungan masingmasing individu. Hasil dari uji hedonik parameter kelenturan pada Tabel 9 menunjukkan bahwa hanya dua sampel perlakuan yang tidak terdapat pada rentang 'biasa' dan 'suka'. A3B2 dan A3B3 adalah sampel dengan kategori antara 'tidak suka' dan 'biasa'. Kesamaan dari kedua sampel ini adalah keduanya diberikan suhu $55^{\circ} \mathrm{C}$. Bila diperhatikan setiap nilainya, nori daun kelor dengan suhu pengeringan $55^{\circ} \mathrm{C}$ memiliki nilai yang paling rendah dibandingkan dengan suhu lainnya. Pada suhu ini juga terlihat bahwa semakin banyak karagenan yang ditambahkan berefek pada berkurangnya tingkat kesukaan panelis pada kelenturan nori daun kelor siap makan. 
Tabel 9. Hasil Uji Hedonik Kelenturan Nori Daun Kelor

\begin{tabular}{cccc}
\hline \multirow{2}{*}{ Suhu Pengeringan } & \multicolumn{3}{c}{ Konsentrasi Karagenan } \\
\cline { 2 - 4 } & $\mathrm{B} 1(1.5 \%)$ & $\mathrm{B} 2(2 \%)$ & $\mathrm{B} 3(2.5 \%)$ \\
\hline $\mathrm{A} 1\left(45^{\circ} \mathrm{C}\right)$ & 3.17 & 3.17 & 3.30 \\
$\mathrm{~A} 2\left(50^{\circ} \mathrm{C}\right)$ & 3.70 & 3.30 & 3.30 \\
$\mathrm{~A} 3\left(55^{\circ} \mathrm{C}\right)$ & 3.13 & 2.80 & 2.63 \\
\hline
\end{tabular}

Keterangan: antara tidak suka dan biasa

antara biasa dan suka

Pada Tabel 10 mengenai hasil uji mutu hedonik kelenturan, terlihat bahwa semua nori daun kelor siap makan yang dikeringkan pada suhu $55^{\circ} \mathrm{C}$ termasuk pada kategori 'tidak lentur' dan 'agak lentur'. Hal ini disebabkan oleh kadar air yang hilang pada bahan selama proses pengeringan. Semakin tinggi suhu yang digunakan pada proses pengeringan, akan menyebabkan semakin banyaknya air yang hilang selama proses tersebut. Hal ini menjadikan nori daun kelor siap makan memiliki kadar air yang semakin sedikit, keras, dan kurang lentur (Rahmi, 2004 dalam Nurfiani, 2017).

Tabel 10. Hasil Uji Mutu Hedonik Kelenturan Nori Daun Kelor

\begin{tabular}{cccc}
\hline \multirow{2}{*}{ Suhu Pengeringan } & \multicolumn{3}{c}{ Konsentrasi Karagenan } \\
\cline { 2 - 4 } & $\mathrm{B} 1(1.5 \%)$ & $\mathrm{B} 2(2 \%)$ & $\mathrm{B} 3(2.5 \%)$ \\
\hline $\mathrm{A} 1\left(45^{\circ} \mathrm{C}\right)$ & 3.13 & 2.83 & 3.20 \\
$\mathrm{~A} 2\left(50^{\circ} \mathrm{C}\right)$ & 3.43 & 3.20 & 2.90 \\
$\mathrm{~A} 3\left(55^{\circ} \mathrm{C}\right)$ & 2.83 & 2.37 & 2.27 \\
\hline
\end{tabular}

Keterangan: antara tidak lentur dan agak lentur antara agak lentur dan lentur

Selain faktor suhu pengeringan, pada Tabel 10 juga terlihat konsetrasi karagenan turut andil dalam membentuk kelenturan nori daun kelor. Hal tersebut juga dapat dilihat pada data bahwa meningkatnya penambahan karagenan cenderung menjadikan nori daun kelor menjadi semakin tidak disukai dan semakin keras. Mengerasnya nori daun kelor seiring dengan meningkatnya karagenan yang ditambahkan terjadi karena pembentukan gel yang semakin kokoh ketika semakin banyak karagenan yang ditambahkan (Harijono dkk., 2001).

\section{KESIMPULAN}

Nori daun kelor dengan berbagai konsentrai dan suhu pengeringan yang diuji memiliki tingkat kesukaan yang sama (antara biasa dan suka) pada parameter warna dan aroma. Nori daun kelor dengan penambahan karagenan 1,5\% memiliki tingkat kesukaan rasa yang lebih rendah dibandingkan dengan penambahan karagenan konsentrasi lain. Pada parameter kelenturan, nori daun kelor dengan pengeringan $55^{\circ} \mathrm{C}$ memiliki tingkat kesukaan yang lebih rendah dibandingkan dengan nori daun kelor dengan suhu pengeringan lainnya. Berdasarkan hasil uji mutu hedonik, nori daun kelor yang dikeringkan pada suhu $45^{\circ} \mathrm{C}$ dan $55^{\circ} \mathrm{C}$ dinilai memiliki warna yang lebih hijau dibandingkan dengan nori yang dikeringkan dengan suhu $50^{\circ} \mathrm{C}$. Pada parameter aroma, daun kelor yang dikeringkan pada suhu $50^{\circ} \mathrm{C}$ lebih tidak beraroma daun dibandingkan dengan nori pada pengeringan suhu lainnya. Untuk parameter rasa, rasa pahit nori daun kelor berkurang seiring dengan bertambahnya konsentrasi kappa karagenan yang digunakan. Pada parameter kelenturan, nori menjadi semakin tidak lentur ketika suhu pengeringan dan konsentrasi kappa karagenan yang digunakan semakin tinggi. 


\section{DAFTAR PUSTAKA}

Agusta, E. N., Amalia, L., \& Hutami, R. (2017). Formulasi Nori Artifisial Berbahan Baku Bayam (Amaranthus hybridus L.). Jurnal Agroindustri Halal, 3(I), 019-027.

Ali, M.A., Yusof, Y.A., Chin, N.L., Ibrahim, M.N., Basra, S.M.A. (2014). Drying Kinetics and Colour Analysis of Moringa Oleifera Leaves. Agriculture and Agricultural Science Procedia, 1, 394-400. ScienceDirect.

Arfandi, A., Ratnawulan, Y. Darvina. (2013). Proses Pembentukan Feofitin Daun Suji Sebagai Bahan Aktif Photosensitizer Akibat Pemberian Variasi Suhu. Pillar of Physics, Vol.1. April 2013, 68-76.

Badan Pusat Statistik. (2015). Statistik Restoran/Rumah Makan 2015. Jakarta: Badan Pusat Statistik.

Burhani, R. (2007). Rumput Laut Papua Diminati Mancanegara. [Online]. Diakses dari Antaranews: antaranews.com/berita/58668/rumput-laut-papua-diminatimancanegara.

Dada, M. (2016). Miracle Tree: A Review on Multi-Purposes of Moringa Oleifera and Its Implication for Climate Change Mitigation. Journal of Earth Science \& Climatic Change, 2157-7617.

Dewi, F. K., Sulasih, N., Garnida, Y. (2016). Pembuatan Cookies dengan Penambangan Tepung Daun Kelor (Moringa oleifera) pada berbagai Suhu Pemanggangan. [Online]. Diakses dari http://repository.unpas.ac.id/26615/1/Artikel.pdf.

Harijono, Kusnadi, Joni, Mustikasari, Setyo, A. (2001). Pengaruh Kadar Karaginan dan Total Padatan Terlarut Sari Buah Apel Muda terhadap Aspek Kualitas Permen Jelly. Jurnal Teknologi Pertanian, 2(2), 110-116.

Hatta, A.M. (1990). Kemungkinan Budidaya Porphyra (Rhodopyta, Bangiales) di Perairan Indonesia. Oseana, 15(1), 1-11.

Kim, J.K., Park, H.G., Kim, C.R., Lim, H.J., Cho, K.M., Choi, J.S., Shin, D.H., Shin, E.C. (2014). Quality Evaluation on Use of Camellia Oil as an Alternative Method in Dried Seaweed Preparation. Korean Society Food Science and Nutrition ,19(3), 234-241.

Marwani, S.A. dan Yuwono, S.S. (2018). Pengaruh Lama Pemasakan dan Konsentrasi Karagenan Terhadap Sifat Fisik, Kimia, dan Organoleptik Selai Lembaran Mix Fruit (Belimbing dan Apel). Jurnal Pangan dan Agroindustri, 6(2), 33-41. jpa: https://jpa.ub.ac.id/index.php/jpa/article/download/585/431

Muchtadi, T., \& Sugiono. (1992). Ilmu Pengetahuan Bahan Pangan. Bogor: Institut Pertanian Bogor.

Negara, J.K. A.K. Sio, Rifkhan, M.Arifin, A.Y. Oktaviana, R.R.S. Wihansah, M. Yusuf. (2016). Aspek Mikrobiologis Serta Sensori (Rasa, Warna, Tekstur, Aroma) pada Dua Bentuk Penyajian Keju yang Berbeda. Jurnal Produksi dan Teknologi Hasil Peternakan. Vol.04 no. 2 Juni 2016.

Nurfiani, D., Sari, N.I., Loekman, S. (2017). Pengaruh Pengeringan Berbeda Terhadap Mutu Nori Rumput Laut (Gracilaria sp). [Online]. Diakses dari https://digilib.unri.ac.id.

Olaofe, O., Adeyeye, E. I., \& Ojugbo, S. (2013). Comparative Study of Proximate, Amino Acids and Fatty Acids of Moringa Oleifera Tree. Elixir International Journal, 1254312554.

Olson, M., Sankaran, R.P., Fahey, J.W., Grusak, M.A., Odee, D., Nouman, W. (2016). Leaf Protein and Mineral Concentrations across the "Miracle Tree" Genus Moringa. PLoS ONE, 11(7).

Patriyanti E.A., Budihastuti, R., Hastuti, E.D. (2016). Pengaruh Suhu Pengeringan ynag Berbeda terhadap Kualitas Cabai Rawit (Capsicum frutescens L.). Jurnal Biologi, $5(1), 82-92$.

Pusdatin. (2015). Statistik Konsumsi Pangan. Diambil kembali dari Pusdatin Pertanian: Epublikasi.setjen.pertanian.go.id 
Rianse, M. I. (2017). Pengaruh Konsentrasi k-Karagenan Terhadap Sifat Fisikokimia dan Organoleptik Produk Vegetable Leather dari Daun Kelor (Moringa oleifera L.). [Skripsi]. Universitas Halu Oleo, Kendari.

Roiyana, M., Prohastanti, E., Kasiyati. (2011). Pengaruh Suhu dan Lama Penyimpanan Daun Stephania hernandifolia Walp. terhadap Kualitas Bahan Baku Cincau dan Penerimaan Konsumen. UNDIP. eprints.undip.ac.id/35927/1/2.pdf.

Soekarto, S.T. (1995). Penilaian Organoleptik untuk Industri Pangan dan Hasil Pertanian. Bharata, Yogyakarta.

Stevani, N., Mustofa, A., \& Wulandari, Yustina W. (2018). Pengaruh lama pengeringan dan penambahan karagenan terhadap karakteristik nori daun kangkung (Ipomoea reptans Poir). Jurnal JITIPARI, 3, 85-96.

Syarifah, I. (2016). Pengaruh Konsentrasi Tepung Kedelai dan Karagenan terhadap Karakteristik "Snack Nori" dari Kulit Buah Naga (Hylocereus costariensis). [Online] diakses dari repository.unpas.ac.id. 